\title{
Poly(ethylene terephthalate-co-isophthalate) Copolyesters Obtained from Ethylene Terephthalate and Isophthalate Oligomers
}

\author{
JOAN UBACH ${ }^{1}$, ANTXON MARTÍNEZ DE ILARDUYA, ${ }^{1, \star}$ ROBERT QUINTANA, ${ }^{1}$ \\ ABDELILAH ALLA, ${ }^{1}$ ELISABET RUDÉ, ${ }^{2}$ SEBASTIÁN MUÑOZ-GUERRA ${ }^{1}$
}

1. Departament d'Enginyeria Química, Universitat Politècnica de Catalunya, ETSEIB, Diagonal 647, E-08028 Barcelona, Spain.

2. Departament d'Enginyeria Química, Universitat de Barcelona, C/Martí i Franquès 1, E-08028 Barcelona, Spain.

antxon.martinez.de.ilarduia@upc.edu

\begin{abstract}
A series of poly(ethylene terephthalate-co-isophthalate) copolyesters containing up to $50 \%$-mole of isophthalic units were prepared by polycondensation from ethylene terephthalate and ethylene isophthalate fractions of linear oligomers containing from 5 to 6 repeating units in average. The polyesters were obtained in good yields and with high molecular weights. The microstructure of the copolyesters was studied as a function of reaction time by ${ }^{13} \mathrm{C}-\mathrm{NMR}$ showing that a random distribution of the comonomers was achieved since the earlier stages of polycondensation. The melting temperature and enthalpy of the copolyesters decreased with the content of isophthalic units so that copolyesters containing more than $25 \%$ of these units were amorphous. Isothermal crystallization studies made on crystalline copolyesters revealed that the crystallization rate of copolyesters decreased with the content in isophthalic units.
\end{abstract}

Keywords: poly(ethylene terephthalate-co-isophthalate), polycondensation, ethylene terephthalate oligomers, NMR, crystallization.

Contract grant sponsors: CICYT Spain. Grant Number MAT2006-12,209-C02 and Artenius Prat (La Seda de Barcelona). Contract Grant Number C-06763. 


\section{INTRODUCTION}

Poly(ethylene terephthalate) (PET) is a semicrystalline thermoplastic currently obtained from terephthalic acid (TPA) and ethylene glycol (EG). It is widely used in the textile and packaging fields to produce fibers, films and bottles ${ }^{1}$ due to its excellent thermal and mechanical properties, high chemical resistance and low permeability to gases. Since for some applications a high transparency is also required, minor amounts of comonomers as diacids ${ }^{2-4}$ or diols ${ }^{5-9}$ are added to repress the tendency of this polymer to crystallize. A review on the thermal properties and crystallization behavior of PET by copolymerization has been published by Kint et al. ${ }^{10}$ The comononers mostly used for such purpose in blowing-injection applications are isophthalic $\operatorname{acid}^{11,12}$ (IPA) and cyclohexanedimethanol ${ }^{13}$ (CHDM) due to the improvement in the barrier properties and impact resistance they provide to their respective resulting copolyesters, as well as diethyleneglicol (DEG), a comonomer that is also effective in repressing polymer crystallization. ${ }^{14}$

Poly(ethylene terephthalate-co-isophthalate) copolyesters $\left(P E T_{x} I_{y}\right)$ where $x$ and $y$ denote the molar content of terephthalate and isopthalate units respectively, are usually obtained by a two stage melt polycondesation process. ${ }^{15,16}$ In the first step TPA and IPA react with EG under slight over-pressure (2-5 bar) at around $250-260{ }^{\circ} \mathrm{C}$ to produce a co-oligomeric mixture containing from 5 to 10 repeating units in average, depending on the excess of glycol added. The molar ratio diacid/glycol frequently used is 1/1.1-1.2 so the final product at the end of the esterification step is a random ethylene terephthalate-co-isophthalate oligomer ending mostly in glycolic units. These co-oligomers are then transferred to the polycondensation reactor or reactors, where temperature is increased at $270-285^{\circ} \mathrm{C}$ and pressure is gradually reduced to 1 mbar to remove the excess of EG produced in the transesterification reaction and to increase therefore the molecular weight. This reaction usually takes around $90 \mathrm{~min}$ in the presence of catalyst $\left(\mathrm{Sb}_{2} \mathrm{O}_{3}, \mathrm{GeO}_{2}\right)$ to afford a fair molecular weight polyester with a random microstructure. An increase in the polycondensation time gives rise to both yellowing and molecular weight decrease due to thermal degradation. Then the strategy to produce high molecular weight copolyesters is to introduce the polymer crystallized as pellets into a solid state polymerization reactor where the polycondensation reaction (SSP) is forced to continue at temperatures near below its melting temperature. ${ }^{17}$

Due to the growing production of $\mathrm{PET}_{\mathrm{x}} \mathrm{l}_{\mathrm{y}}$ copolyesters, new synthesis methodologies and industrial processes are being explored nowdays. ${ }^{18,19}$ However, as 
far as we know, none of them use linear oligomers as the starting material. This approach would be readily applicable by simple implementation of the common PET line production with an additional esterification reactor where ethylene isophthalate oligomers were produced and then loaded to the reaction vessel just before the polycondensation step. In this work we have studied the preparation of $P E T_{x} I_{y}$ copolyesters by polycondensation reaction of mixtures of ethylene terephthalate and ethylene isophthalate linear oligomers which were previously synthesized for this purpose. The evolution of the microstructure with reaction time is assessed by ${ }^{13} \mathrm{C}$ NMR and the thermal properties and crystallizability of the copolyesters are evaluated by DSC and TGA.

\section{EXPERIMENTAL SECTION}

\section{Materials}

Terephthalic acid (TPA) (99\%), isophthalic acid (IPA) (99\%), ethylene glycol (EG) (99\%) and germanium dioxide (99\%) were kindly supplied by Artenius Prat (La Seda de Barcelona S.A.) and used without further purification. Dichloro acetic acid and diethyl ether used for purification and other analytical purposes were analytical grade (Aldrich) and used as received.

\section{Synthesis}

The procedure applied for the synthesis of PET and PEI oligomers (OET and OEl, respectively) was as follows: $350 \mathrm{~g}$ of TPA or IPA (2.11 mol), $157.2 \mathrm{~g}$ of EG (2.53 $\mathrm{mol}$ ) and $0.1 \mathrm{~g}$ of $\mathrm{GeO}_{2}$ catalyst $(0.95 \mathrm{mmol})$ were added to a Karl Kurl Juchheim stainless steel reactor of $1.5 \mathrm{~L}$ equipped with a distillation column, a condenser, a nitrogen inlet, a drain valve and a mechanical anchor stirrer. Firstly the pressure of the reactor was set at 3 bar and the temperature was gradually increased to $255^{\circ} \mathrm{C}$ and maintained at this temperature for 70 min under vigorous agitation. Then, atmospheric pressure was recovered and the reaction temperature was increased to $260{ }^{\circ} \mathrm{C}$ and maintained for $5 \mathrm{~min}$. Finally the linear oligomers were collected from the reactor through the drain valve and characterized by NMR and end group titration with a base.

For the synthesis of $\mathrm{PET}_{\mathrm{x}} \mathrm{I}_{\mathrm{y}}$ copolymers the following procedure was applied: About $30 \mathrm{~g}$ of mixtures of PET and PEI linear oligomers obtained as described above were placed in a three-necked $100 \mathrm{~mL}$ round-bottom flask equipped with a mechanical 
stirrer, a nitrogen inlet and a vacuum distillation outlet. Molar ratios $x / y$ ranging from 96/4 to 50/50 were assayed. The flask was introduced into a nitrate salt bath and the temperature was increased to $260{ }^{\circ} \mathrm{C}$ and maintained at this temperature for $30 \mathrm{~min}$. The pressure was gradually reduced to $1 \mathrm{mbar}$ for a period of $30 \mathrm{~min}$ and the temperature was gradually increased up to $290{ }^{\circ} \mathrm{C}$, and the polycondensation left to proceed under such conditions for $90 \mathrm{~min}$. After this period of time, the release of EG ceased and a viscous liquid was finally obtained. The reaction mixture was then cooled to room temperature and the atmospheric pressure was recovered with a nitrogen flow to prevent degradation. The solid mass was dried at $60{ }^{\circ} \mathrm{C}$ under reduced pressure for 48 hours previous to characterization.

\section{Measurements}

Intrinsic viscosities of the polymers dissolved in dichloroacetic acid were measured using an Ubbelohde viscosimeter thermostated at $25 \pm 0.1{ }^{\circ} \mathrm{C}$. Gel permeation chromatography (GPC) was carried out using an o-chlorophenol/chloroform mixture $(1 / 9 \mathrm{v} / \mathrm{v})$ as the mobile phase at $35^{\circ} \mathrm{C}$. GPC analyses were performed in a Waters system equipped with both refractive-index and light scattering detectors. Two 7.8 x $300 \mathrm{~mm}$ Styragel columns packed with divinylbenzene crosslinked polystyrene (pore size $10^{3}$ and $10^{4} \AA$ ) in series were used for the analysis. The flow rate of the eluent was $0.5 \mathrm{~mL} \cdot \mathrm{min}^{-1}$. Molecular weights and molecular weights distributions were estimated against monodisperse poly(methyl methacrylate) standards using the Maxima 820 software.

Carboxylic end group was determined by potentiometric tritration using a Metrohm 726 titroprocesor. For that $0.5 \mathrm{~g}$ of OET or OEI oligomers were dissolved in $20 \mathrm{~mL}$ of $o$-cresol to which $50 \mathrm{~mL}$ of chloroform were added. The solution was titrated with $0.1 \mathrm{M}$ tetrabutyl ammonium hydroxide and the $[\mathrm{COOH}]$ was expressed in meq $\cdot \mathrm{kg}^{-1}$.

NMR spectra were recorded at $25 \pm 0.1^{\circ} \mathrm{C}$ on a Bruker AMX-300 spectrometer operating at $300.1 \mathrm{MHz}$ and $75.5 \mathrm{MHz}$ for ${ }^{1} \mathrm{H}$ and ${ }^{13} \mathrm{C}$ respectively. $10 \mathrm{mg}\left({ }^{1} \mathrm{H}-\mathrm{NMR}\right)$ and $50 \mathrm{mg}\left({ }^{13} \mathrm{C}-\mathrm{NMR}\right)$ of sample were dissolved in $1 \mathrm{~mL}$ of deuterated trifluoroacetic acid or a mixture of deuterated chloroform/trifluoroacetic acid (9/1 v/v) solvents for NMR analysis. The spectra were internally referenced to the signal of tetramethylsilane (TMS). 64 scans were acquired for ${ }^{1} \mathrm{H}$ and $5,000-10,000$ for ${ }^{13} \mathrm{C}$ with 32 and $64 \mathrm{~K}$ data points respectively. For the analysis of the microstructure, ${ }^{13} \mathrm{C}-\mathrm{NMR}$ spectra were Fourier transformed (FT) with 128K providing a digital resolution of $0.27 \mathrm{~Hz}$ per point. Integration of the overlapping signals was made by Lorentzian deconvolution of the spectra using the Bruker 1D WIN-NMR software. 
DSC experiments were performed on a PerkinEImer Pyris 1 instrument calibrated with indium. Thermograms were obtained from 4-6 mg samples at heating and cooling rates of $10^{\circ} \mathrm{C} \cdot \mathrm{min}^{-1}$ under a nitrogen flow of $20 \mathrm{~mL} \cdot \mathrm{min}^{-1}$, except for determination of glass transition temperatures, where the heating rate was $20^{\circ} \mathrm{C} \cdot \mathrm{min}^{-1}$. Isothermal crystallization studies were performed on amorphous quenched films at different temperatures. Thermogravimetric analysis (TGA) were carried out on a PerkinElmer TGA-6 thermobalance at a heating rate of $10^{\circ} \mathrm{C} \cdot \mathrm{min}^{-1}$ under a nitrogen atmosphere.

\section{RESULTS AND DISCUSSION}

The $P E T_{x} l_{y}$ copolyesters described in this work were prepared by a two-step melt polycondensation reaction as indicated in Scheme I.

\section{Scheme I}

Firstly the ethylene terephthalate and ethylene isophthalate oligomers were produced separately. This step requires working at a slight over pressure in order to increase the reaction temperature to the value at which both the terephthalic and isophthalic acids become almost soluble in EG. The chemical structure of the oligomeric fractions was characterized by NMR and their sizes were determined using end group data afforded by NMR and carboxyl end group titration. The content in hydroxyl end groups expressed in meq. $\mathrm{kg}^{-1}$ was estimated by integration of the signals at 4.8 and $4.2 \mathrm{ppm}$ arising from the oxyethylen and hydroxyethylen end groups respectively using the following expression:

$$
[\mathrm{OH}]=\left[\mathrm{CH}_{2} \mathrm{OH}\right]=1000 * 1000 / 192.2 * \mathrm{a} / 2 / \mathrm{b} / 4
$$

where $a$ and $b$ are the integrals at 4.2 and 4.8 respectively.

The content in carboxylic end groups were measured by titration with tetrabutyl ammonium hydroxide.

From the values of $[\mathrm{OH}]$ and $[\mathrm{COOH}]$ the number average degree of polymerization $\left(x_{n}\right)$ can be calculated using the following expression:

$$
x_{n}=[U R] / 1 / 2[G T]=1000 * 1000 / 192.2 / 1 / 2([O H]+[C O O H])
$$


where [UR] and [GT] are the repeating units and terminal groups concentrations respectively.

As it can be seen in Table I, a number average of 5.7 and 5.4 repeating units were calculated for OET and OEI oligomers, for which around 15 and 20\% of carboxylic end groups were found, respectively. These values are close to 5 , which is the value theoretically calculated for a relation diacid/EG of $1 / 1.2$

\section{Table I}

In the second step, which was carried out in the polycondensation reactor, OET and OEI oligomers were blended in the required proportions to obtain the corresponding copolyesters with the chosen compositions. The reaction was carried out at higher temperature $\left(290^{\circ} \mathrm{C}\right)$ and under vacuum to remove the excess of EG added in the feed. The copolyesters obtained are listed in Table II, where the feed content, viscosity, molecular weights and polydispersity are given for each sample. The intrinsic viscosity of the copolyesters was between $0.7-0.8 \mathrm{dL} \cdot \mathrm{g}^{-1}$ indicating that the copolymers have moderate molecular weights. The GPC analysis afforded higher values but with a tendency fully consistent with the observed viscosities. They all have polydispersities around 2 .

\section{Table II}

The chemical structure of the polyesters was ascertained by NMR spectroscopy. ${ }^{1} \mathrm{H}-\mathrm{NMR}$ spectra in solution afforded clear differences in the chemical shifts of the signals arising from ET and El units, which could be used to estimate the copolymer composition, ${ }^{13} \mathrm{C}$-NMR spectra were used to determine the microstructure of the copolymer chain. Figure 1 shows the ${ }^{1} \mathrm{H}$ and ${ }^{13} \mathrm{C}$-NMR spectra of $\mathrm{PET}_{60} \mathrm{l}_{40}$ copolyesters obtained with peak assignments as a representative example of the family. Signal $f$ and $d$ of isophthalic and terephthalic protons respectively were used to calculate the copolymer composition. As it can be seen in Table III a good correlation between the feed and final compositions was found in all cases. Additionally, ${ }^{1} \mathrm{H}-\mathrm{NMR}$ spectra showed small peaks at 4.1 and $4.7 \mathrm{ppm}$ due to the presence of diethylene glycol units presumably resulting from side reactions taking place along both esterification and polycondensation steps. The content of these units was estimated to be around $5 \%$ in all cases. 
In order to investigate the microstructure of the resulting copolyesters, the evolution of ${ }^{13} \mathrm{C}$-NMR spectra with polycondensation time was recorded. As it was reported before, ${ }^{22}$ the non protonated aromatic carbons of isophthalic and terephthalic units were sensitive to sequence distribution at the level of dyads and triads respectively. These signals were therefore used to estimate the number average sequence lengths and randomness of the copolymer that was generated as the reaction proceeded. Figure 2 shows the ${ }^{13} \mathrm{C}-\mathrm{NMR}$ spectra for the $\mathrm{PET}_{50} \mathrm{I}_{50}$ copolyester, the initial mixture of the OET y OEI oligomers, the product resulting at the end of the esterification step and the copolymer formed at progressively longer polycondensation times.

\section{Figure 2}

As it is shown in Figure 2, the signals that in the physical mixture appear as single peaks (labeled as 1), at the end of the esterification step were split in 4 and 2 peaks for the quaternary aromatic carbons of terephthalate and isophthalate units respectively (labeled as 2 and 6). By integration of such peaks the evolution of the average sequence lengths and randomness of the copolymer could be evaluated as a function of reaction time. As it can be observed in Table IV, the copolyesters obtained at the end of the esterification step display a certain blocky microstructure, whereas those obtained after polycondensation were almost random even after short reaction times. These results evidence that the transesterification processes leading to randomization occur very fast at $290{ }^{\circ} \mathrm{C}$ in these low viscosity oligoesters. As a consequence, the resulting $\mathrm{PET}_{\mathrm{x}} \mathrm{l}_{\mathrm{y}}$ copolyesters have a microstructure practically undistinguishable from that present in these type of copolyesters obtained by polycondensation of the monomers. ${ }^{23}$

\section{Table IV}

The thermal behavior of $\mathrm{PET}_{\mathrm{x}} \mathrm{l}_{\mathrm{y}}$ of copolyesters was examined by DSC and TGA. As it can be seen in Table $V$, both melting temperature and enthalpy decrease as the content in isophthalate units increase to the point that the copolyester becomes unable to crystallize when the contents of these units is higher than $25 \%$. Due to the amorphous nature of these copolyesters with high contents in isopthalate units, they showed improved solubility in organic solvents, being soluble in $\mathrm{CHCl}_{3}$, where PET was 
observed to be not soluble. The effect of composition on $T_{g}$ is similar; this temperature gradually decreases with the content of isophthalate units taking values in the range limited by the $T_{\mathrm{g}}$ of PET and PEI homopolyesters. The polymers were thermally stable up to almost $400{ }^{\circ} \mathrm{C}$ and no remarkable differences could be observed among the components of the series.

\section{Table V}

Finally the crystallization kinetics parameters of the crystallizable copolyesters $\mathrm{PET}_{94} \mathrm{I}_{6}$ and $\mathrm{PET}_{90} \mathrm{I}_{10}$ were determined from isothermal crystallizations experiments carried out at different temperatures (Table VI and Figure 3). The Avrami exponent $n$, was shown to increase with temperature from values below 2 to values near to 3 revealing that a change in the crystal growth process from two-dimensional to threedimensional spherulitic growth likely took place with increasing in crystallization temperature. Comparison of the crystallization half time for the two copolyesters for the same degree of undercooling revealed that crystallization was delayed in $\mathrm{PET}_{90} \mathrm{I}_{10}$. As expected, crystallizability is significantly repressed by the incorporation of isophthalate units in the copolyester. Similar conclusions were obtained in the work of Wu et al. ${ }^{24}$ on PETI copolyesters obtained from melt polycondensation.

\section{Table VI, Figure 3}

\section{CONCLUSIONS}

PET copolyesters containing different amounts of isophthalate units could be prepared from ethylene terephthalate and isophthalate linear oligomers. The copolyesters obtained showed a random microstructure which was attained since the earlier stages of polycondensation. The copolyesters were amorphous for contents in isophthalic units higher than $25 \%$. It was shown that the melting temperature and crystallinity decreased with the incorporation of isophthalic units as well as the crystallizability. Additionally the copolymers showed glass transition temperatures between the one of PET and PEI. These findings support that these copolymers have similar microstructure and properties to the ones obtained by the conventional twostage melt polycondensation of terephthalic and isophthalic acids with ethylene glycol. 


\section{References}

1. Gupta V.B.; Bashir Z., In Handbook of Thermoplastics Polyesters, Fakirov, S. Ed.; Wiley-VCH, Weinheim, 2002, Chap 7.

2. Lu T.S.; Sun Y.M.; Wang C.S. J. Polym. Sci. Polym. Chem. 1995, 33, 2841.

3. Polyakova A.; Connor D.M.; Collard D.M; Schiraldi D.A.; Hiltner A.; Baer E. J. Polym. Sci. Polym. Phys. 2001, 39, 1900.

4. Kint D.P.R., Martínez de Ilarduya A.; Munoz-Guerra S. J. Polym. Sci. Polym. Chem. 2001, 39, 1994.

5. Bouma K.; Regelink M.; Gaymans R.J. J. Appl. Polym. Sci., 2001, 80, 2676.

6. Turner S.R.; King B.; Ponasik J.; Adams V.; Connell G. High Perform. Polym. 2005, $17,361$.

7. Kelsey D.R.; Scardino B.M.; Grebowicz J.S.; Chuah H.H. Macromolecules, 2000, 33, 5810.

8. Kiyotsukuri T.; Masuda T.; Tsusumi N. Polymer 1994, 35, 1274.

9. Lee J.W.; Lee, S.W.; Lee B.; Moonhor R. Macromol. Chem. Phys. 2001, 202, 3072.

10. Kint D.P.R.; Muñoz-Guerra S. Polym. Int. 2003, 52, 321.

11. Hu Y.S.; Hiltner A.; Baer E. J. Appl. Polym. Sci. 2005, 98, 1629.

12. Liu R.Y.F.; Hu Y.S.; Hibbs M.R.; Collard D.M.; Schiraldi D.A.; Hiltner A.; Baer E. J. Appl. Polym. Sci. 2005, 98, 1615.

13. Turner S.R.; Seymour R.W.; Dombroski J.R., In Modern Polyesters: Chemistry and Technology of Polyesters and Copolyesters, Scheirs J.; Long T.E. Eds. Wiley Chichester, West Sussex, UK, 2003, Chap 7.

14. Lee S.W.; Lee B.; Ree M. Macromol. Chem. Phys. 2000, 201, 453.

15. Lee S.W.; Ree M.; Park C.E.; Jung Y.K.; Park C.-S.; Jin Y.S.; Bae D.C. Polymer 1999, 40, 7137.

16. Fradet A.; Tessier M., In Synthetic Methods In Step-Growth Polymers, Rogers M.R.; Long T.E. Eds. John Wiley \& Sons, Inc., New Jersey, 2003, Chap. 2. 
17. Culbert B.; Christel A., In Modern Polyesters: Chemistry and Technology of Polyesters and Copolyesters, Scheirs J.; Long T.E. Eds. Wiley Chichester, West Sussex, UK, 2003, Chap 4.

18. MacDonald W.A. Polym. Int. 2002, 51, 923.

19. Pang K.; Kotek R.; Tonelli A. Prog. Polym. Sci. 2006, 31, 1009.

20. Moore W.R; Sanderson S. Polymer 1968, 3, 153.

21. Randall J.C. Polymer Sequence Determination. Academic Press. New York, 1977, Chap. 4.

22. Martínez de Ilarduya A.; Kint D.P.R.; Muñoz-Guerra S. Macromolecules 2000, 33, 4596.

23. Economy J.; Schneggenburger, L.A.; Frich D., In Transreactions in Condensation Polymers, Fakirov S. Ed. Wiley-VCH, Weinheim (Germany) 1999, Chap 5.

24. Wu T-M.; Chang C-C. J. Polym. Sci. Polym. Phys. 2000, 38, 2515. 


\section{Figure Captions}

Scheme I. Synthetic route to obtain $\mathrm{PET}_{\mathrm{x}} \mathrm{I}_{\mathrm{y}}$ copolyesteres: (a) First step: esterification (b) Second step: polycondensation.

Figure $1 .{ }^{13} \mathrm{C}-(\mathrm{a})$ and ${ }^{1} \mathrm{H}-(\mathrm{b}) \mathrm{NMR}$ spectra of $\mathrm{PET}_{60} \mathrm{I}_{40}$.

Figure 2. Evolution of ${ }^{13} \mathrm{C}-\mathrm{NMR}$ spectra of $\mathrm{PET}_{50} \mathrm{I}_{50}$ with time. 1: mixture of equimolar amounts of the two oligomers before reaction; 2: product resulting at the end of the esterification step; 3, 4, 5 and 6: copolyesters obtained at 15, 3045 and 90 min of polycondensation reaction.

Figure 3. Relative crystallinity $X_{\mathrm{t}}$ versus crystallization time at different temperatures for isothermally crystallized $\mathrm{PET}_{94} \mathrm{I}_{6}(\mathrm{a})$ and $\mathrm{PET}_{90} \mathrm{I}_{10}$ (b) at the indicated temperatures, and their respective Avrami plots (a') and (b'). 


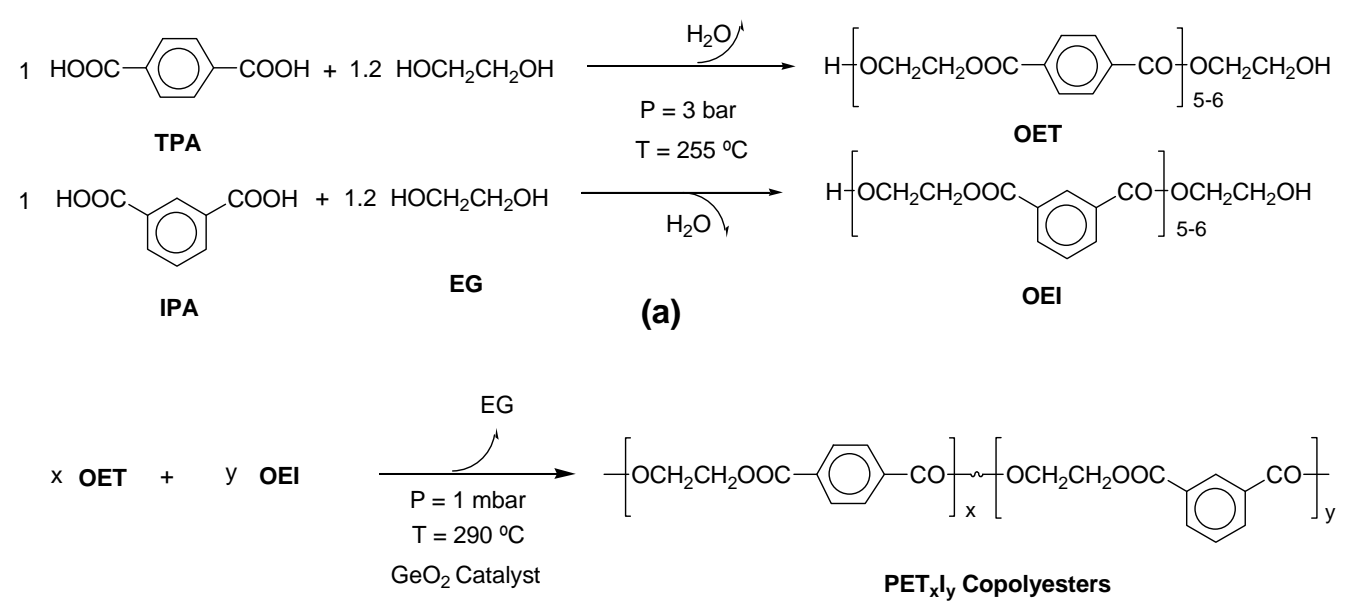

(b)

\section{Scheme 1}
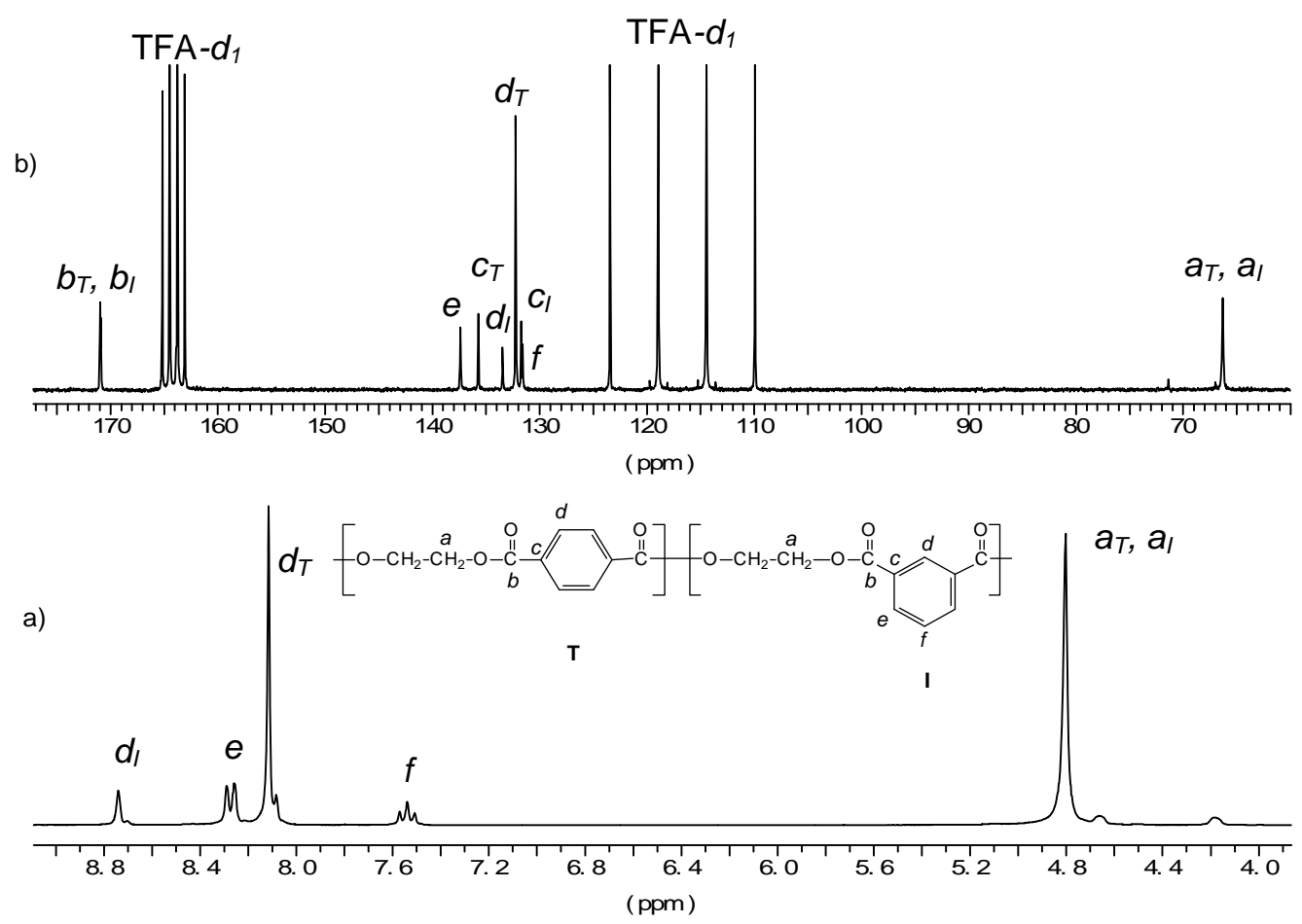

Figure 1 


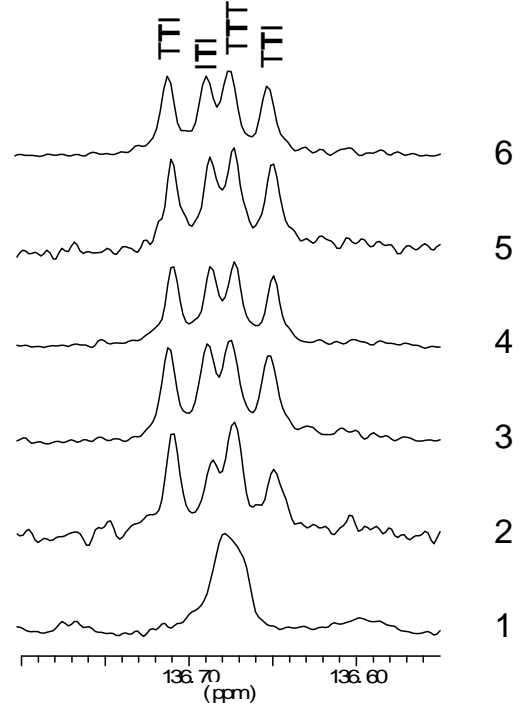

(a)

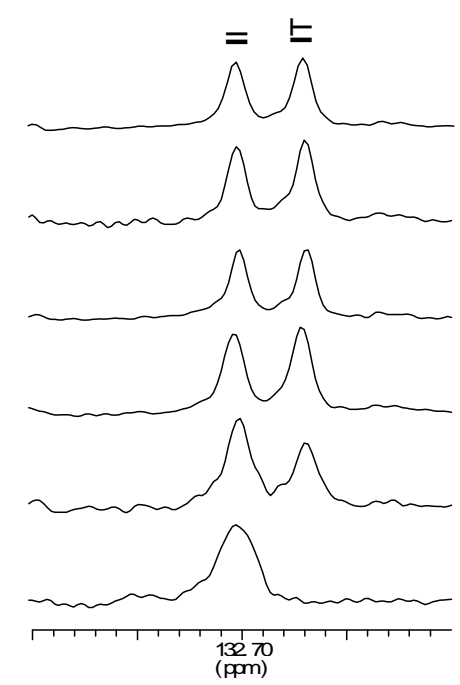

(b)

Figure 2
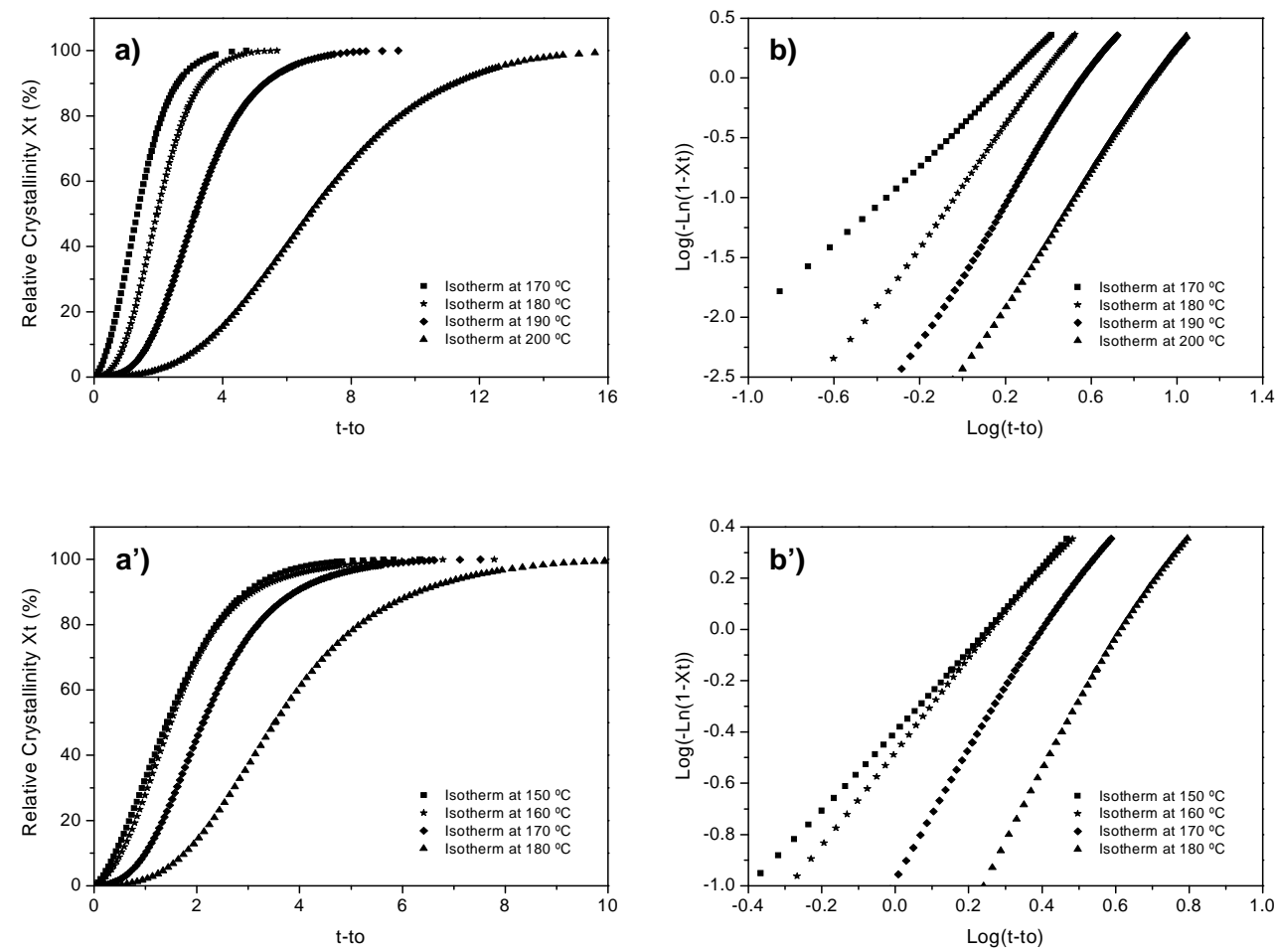

Figure 3 
Table I. Molecular Weights of Ethylene Terephthalate and Ethylene Isophthalate Oligomers.

\begin{tabular}{lcccc}
\hline Oligoester & $\begin{array}{c}{[\mathrm{COOH}]^{\mathrm{a}}} \\
\left(\mathrm{meq} \cdot \mathrm{kg}^{-1}\right)\end{array}$ & $\begin{array}{c}{[\mathrm{OH}]^{\mathrm{b}}} \\
\left(\mathrm{meq} \cdot \mathrm{kg}^{-1}\right)\end{array}$ & $\mathrm{x}_{\mathrm{n}}^{\mathrm{c}}$ & $\begin{array}{c}\mathrm{Mn}^{\mathrm{c}} \\
\left(\mathrm{g} \cdot \mathrm{mol}^{-1}\right)\end{array}$ \\
\hline OET & 393 & 1418 & 5.7 & 1095 \\
OEI & 271 & 1639 & 5.4 & 1045
\end{tabular}

a Determined by potentiometric titration

${ }^{6}$ Values obtained by integration of $\mathrm{CH}_{2} \mathrm{OH}$ and $\mathrm{CH}_{2} \mathrm{OOC}$ signals in the ${ }^{1} \mathrm{H}$ NMR spectra. ${ }^{c} x_{n}=10405.8 /[\mathrm{COOH}]+[\mathrm{OH}]$

Table II. Molecular Weights and Viscosities of PETI Copolyesters.

\begin{tabular}{|c|c|c|c|c|c|c|}
\hline \multirow[b]{2}{*}{ Polyester } & \multirow{2}{*}{$\begin{array}{c}\text { Feed } \\
\text { Composition }^{a} \\
{[\mathrm{OET}] /[\mathrm{OEI}]}\end{array}$} & \multicolumn{5}{|c|}{ Molecular Weights } \\
\hline & & {$[\eta]^{\mathrm{b}}$} & $M_{n}{ }^{c}$ & $M_{n}{ }^{d}$ & $\mathrm{M}_{\mathrm{w}}{ }^{\mathrm{d}}$ & $P D^{d}$ \\
\hline PET & $100 / 0$ & 0.86 & 30600 & 43200 & 103700 & 2.4 \\
\hline $\mathrm{PET}_{94} \mathrm{I}_{6}$ & $94 / 6$ & 0.83 & 28392 & 36500 & 83900 & 2.3 \\
\hline $\mathrm{PET}_{90} \mathrm{I}_{10}$ & $90 / 10$ & 0.82 & 27600 & 34400 & 78600 & 2.4 \\
\hline $\mathrm{PET}_{75} \mathrm{I}_{25}$ & $75 / 25$ & 0.88 & 32100 & 41500 & 99100 & 2.4 \\
\hline $\mathrm{PET}_{70} \mathrm{I}_{30}$ & $70 / 30$ & 0.88 & 32100 & 47000 & 113100 & 2.4 \\
\hline $\mathrm{PET}_{60} \mathrm{I}_{40}$ & $40 / 60$ & 0.72 & 20900 & 37500 & 84100 & 2.2 \\
\hline $\mathrm{PET}_{50} \mathrm{I}_{50}$ & $50 / 50$ & 0.70 & 19700 & 38100 & 83200 & 2.2 \\
\hline
\end{tabular}

${ }^{\text {a }}$ Molar ratio in the initial feed.

dichloracetic acid at $25^{\circ} \mathrm{C}$

${ }^{4}$ Number- and weight average molecular weights and polydispersity determined by GPC.

Table III. Composition, ${ }^{a}$ Diethylene Glycol Content, and Microstructure ${ }^{\mathrm{b}}$ of PETI Copolyesters.

\begin{tabular}{|c|c|c|c|c|c|c|c|c|c|c|c|}
\hline \multirow[b]{2}{*}{ Copolyester } & \multicolumn{2}{|c|}{ Composition $^{a}$} & \multirow{2}{*}{$\begin{array}{l}\mathrm{DEG}^{\mathrm{c}} \\
(\mathrm{mol} \%)\end{array}$} & \multicolumn{3}{|c|}{ Triads (mol \%) } & \multicolumn{2}{|c|}{ Dyads (mol \%) } & \multicolumn{2}{|c|}{$\begin{array}{l}\text { Number Average } \\
\text { Sequence Length }\end{array}$} & \multirow{2}{*}{$\begin{array}{c}\text { Randomness } \\
B \\
\end{array}$} \\
\hline & $X_{T}$ & $X_{I}$ & & TIT & IIT & III & $\underline{\underline{I}}$ & $\underline{I I}$ & $n_{\mathrm{T}}$ & $n_{1}$ & \\
\hline \multirow[t]{2}{*}{$\mathrm{PET}_{94} \mathrm{l}_{6}$} & 94.1 & 5.9 & 5.5 & 84.5 & 9.6 & 0.0 & 5.9 & 0.0 & 15.1 & 1.0 & 1.07 \\
\hline & & & & (83.3) & (10.4) & $(0.3)$ & (5.6) & $(0.3)$ & (16.9) & (1.1) & $(1.00)$ \\
\hline \multirow[t]{2}{*}{$\mathrm{PET}_{90} \mathrm{I}_{10}$} & 89.9 & 10.1 & 5.6 & 72.1 & 13.8 & 3.9 & 9.1 & 1.0 & 9.7 & 1.1 & 1.00 \\
\hline & & & & (72.6) & (16.3) & $(0.9)$ & (9.1) & (1.0) & $(9.9)$ & (1.1) & $(1.00)$ \\
\hline \multirow[t]{2}{*}{$\mathrm{PET}_{75} \mathrm{I}_{25}$} & 75.5 & 24.5 & 5.1 & 43.8 & 27.6 & 4.1 & 18.4 & 6.1 & 4.1 & 1.3 & 0.99 \\
\hline & & & & $(43.4)$ & (27.9) & (4.5) & (18.5) & $(6.0)$ & (4.1) & (1.3) & $(1.00)$ \\
\hline \multirow[t]{2}{*}{$\mathrm{PET}_{70} \mathrm{I}_{30}$} & 70.3 & 29.7 & 5.4 & 33.7 & 28.9 & 7.6 & 20.1 & 9.6 & 3.4 & 1.5 & 0.97 \\
\hline & & & & (34.7) & (29.4) & $(6.2)$ & (20.9) & (8.8) & (3.4) & (1.4) & $(1.00)$ \\
\hline \multirow[t]{2}{*}{$\mathrm{PET}_{40} \mathrm{I}_{60}$} & 60.7 & 39.3 & 4.9 & 21.5 & 28.4 & 10.8 & 23.4 & 15.9 & 2.5 & 1.7 & 0.99 \\
\hline & & & & (22.4) & (29.0) & (9.4) & (23.9) & (15.4) & (2.5) & (1.6) & $(1.00)$ \\
\hline \multirow[t]{2}{*}{$\mathrm{PET}_{50} \mathrm{I}_{50}$} & 50.7 & 49.2 & 4.9 & 14.3 & 24.6 & 11.8 & 24.9 & 24.3 & 2.1 & 2.0 & 0.98 \\
\hline & & & & (13.0) & (25.3) & (12.3) & (24.9) & (24.2) & (2.0) & (2.0) & $(1.00)$ \\
\hline
\end{tabular}

${ }^{\mathrm{a}}$ Determined from the aromatic proton resonances observed in ${ }^{1} \mathrm{H}$-NMR spectra

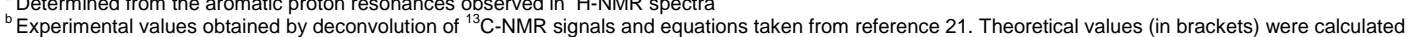
on the basis of a random distribution using the copolyester composition data given in this table.

${ }^{\mathrm{c}}$ Determined from the ${ }^{1} \mathrm{H}$-NMR spectra. 
Table IV. Evolution of Microstructure ${ }^{\mathrm{a}}$ and Randomness Degree of $\mathrm{PET}_{50} \mathrm{I}_{50}$ Copolyester with Reaction Time.

\begin{tabular}{|c|c|c|c|c|c|c|c|c|c|}
\hline \multirow[b]{2}{*}{ Copolyester } & \multirow{2}{*}{$\begin{array}{l}\text { Polycondensation } \\
\text { Time } \\
\text { (min) }\end{array}$} & \multicolumn{3}{|c|}{ Triads (mol \%) } & \multicolumn{2}{|c|}{ Dyads (mol \%) } & \multicolumn{2}{|c|}{$\begin{array}{l}\text { Number Average } \\
\text { Sequence Length }\end{array}$} & \multirow{2}{*}{$\begin{array}{c}\text { Randomness } \\
B\end{array}$} \\
\hline & & TIIT & IIT & III & $\underline{I T}$ & !I & $n_{\mathrm{T}}$ & $n_{1}$ & \\
\hline \multirow[t]{5}{*}{$\mathrm{PET}_{50} \mathrm{I}_{50}$} & 0 & 17.6 & 25.8 & 6.5 & 17.3 & 32.7 & 2.7 & 2.8 & 0.73 \\
\hline & 15 & 12.4 & 24.7 & 12.9 & 26.3 & 23.7 & 2.0 & 1.9 & 1.03 \\
\hline & 30 & 13.3 & 25.0 & 11.7 & 24.1 & 25.9 & 2.1 & 2.1 & 0.96 \\
\hline & 45 & 12.5 & 25.0 & 12.6 & 25.3 & 24.7 & 2.0 & 2.0 & 1.00 \\
\hline & 90 & 14.3 & 24.6 & 11.8 & 24.9 & 24.3 & 2.1 & 2.0 & 0.98 \\
\hline
\end{tabular}

${ }^{\text {a }}$ Experimental values obtained by deconvolution of ${ }^{13} \mathrm{C}$-NMR signals and equations taken from reference 9.

Table V. Thermal Properties of PET, PEI, and PET $T_{x} l_{y}$ Copolyesters.

\begin{tabular}{|c|c|c|c|c|c|c|c|c|c|c|}
\hline \multirow[b]{3}{*}{ Polyester } & \multicolumn{7}{|c|}{ DSC } & & & \\
\hline & \multicolumn{3}{|c|}{ First Heating $^{b}$} & \multicolumn{2}{|c|}{ Cooling $^{b}$} & \multicolumn{2}{|c|}{$\begin{array}{l}\text { Second } \\
\text { Heating }^{b}\end{array}$} & \multicolumn{3}{|c|}{ TGA } \\
\hline & $\begin{array}{c}T_{g}^{\mathrm{a}} \\
\left({ }^{\circ} \mathrm{C}\right)\end{array}$ & $\begin{array}{c}T_{m} \\
\left({ }^{\circ} \mathrm{C}\right)\end{array}$ & $\begin{array}{c}\Delta H_{\mathrm{m}} \\
\left(\mathrm{J} \cdot \mathrm{g}^{-1}\right)\end{array}$ & $\begin{array}{c}T_{c} \\
\left({ }^{\circ} \mathrm{C}\right)\end{array}$ & $\begin{array}{c}\Delta H_{\mathrm{c}} \\
\left(\mathrm{J} \cdot \mathrm{g}^{-1}\right)\end{array}$ & $\begin{array}{c}T_{m} \\
\left({ }^{\circ} \mathrm{C}\right)\end{array}$ & $\begin{array}{c}\Delta H_{\mathrm{m}} \\
\left(\mathrm{J} \cdot \mathrm{g}^{-1}\right)\end{array}$ & $\begin{array}{l}{ }^{\circ} T_{d}{ }^{\mathrm{c}} \\
\left.{ }^{\circ} \mathrm{C}\right)\end{array}$ & $\begin{array}{c}T_{d}{ }^{\mathrm{d}} \\
\left({ }^{\circ} \mathrm{C}\right)\end{array}$ & $\begin{array}{l}\text { RW }^{\mathrm{e}} \\
(\%)\end{array}$ \\
\hline PET & 79.4 & 245.3 & 34.2 & 192.4 & 32.1 & 246.1 & 31.1 & 413 & 440 & 16.6 \\
\hline $\mathrm{PET}_{94} \mathrm{I}_{6}$ & 77.4 & 231.2 & 32.1 & 165.9 & 23.8 & 230.5 & 33.1 & 409 & 441 & 12.8 \\
\hline $\mathrm{PET}_{90} \mathrm{l}_{10}$ & 76.8 & 221.9 & 26.2 & 157.3 & 23.3 & 222.2 & 26.5 & 392 & 439 & 14.3 \\
\hline $\mathrm{PET}_{75} \mathrm{I}_{25}$ & 72.7 & - & - & - & - & - & - & 411 & 437 & 18.8 \\
\hline $\mathrm{PET}_{70} \mathrm{I}_{30}$ & 72.4 & - & - & - & - & - & - & 415 & 436 & 18.8 \\
\hline $\mathrm{PET}_{60} \mathrm{I}_{40}$ & 71.4 & - & - & - & - & - & - & 412 & 440 & 14.8 \\
\hline $\mathrm{PET}_{50} \mathrm{I}_{50}$ & 70.0 & - & - & - & - & - & - & 414 & 442 & 16.2 \\
\hline PEI & 64.7 & - & - & - & - & - & - & 414 & 446 & 16.1 \\
\hline
\end{tabular}

${ }^{a}$ Glass-transition temperature taken as the inflection point of the heating DSC recorded at $30^{\circ} \mathrm{C} \cdot \mathrm{min}^{-1}$ from samples quenched from the melt.

${ }^{\mathrm{b}}$ Melting $\left(T_{m}\right)$ and crystallization $\left(T_{c}\right)$ temperatures and their respective enthalpies $\left(\Delta H_{m}, \Delta H_{c}\right)$ measured by DSC at heating / cooling rates of $10^{\circ} \mathrm{C} \min ^{-1}$.

${ }^{\mathrm{c}}$ Temperature at which a $10 \%$ weight loss was observed in the TGA traces recorded at $10{ }^{\circ} \mathrm{C} \mathrm{min}^{-1}$.

Temperature of maximum degradation rate.

${ }^{\mathrm{f}}$ Remaining weight at $550^{\circ} \mathrm{C}$.

Table VI. Crystallization Parameters of $\mathrm{PET}_{94} \mathrm{I}_{6}$ and $\mathrm{PET}_{90} \mathrm{I}_{10}$ Copolyesters at Different Temperatures.

\begin{tabular}{|c|c|c|c|c|c|c|c|c|c|}
\hline \multirow[b]{3}{*}{$\begin{array}{l}\text { Crystallization } \\
\text { temperature }\end{array}$} & \multicolumn{4}{|c|}{$\mathrm{PET}_{94} \mathrm{I}_{6}$} & \multicolumn{5}{|c|}{$\mathrm{PET}_{90} \mathrm{l}_{10}$} \\
\hline & \multicolumn{4}{|c|}{ Avrami Parameters $^{a}$} & \multirow[b]{2}{*}{$\begin{array}{l}\text { Crystallization } \\
\text { temperature }\end{array}$} & \multicolumn{4}{|c|}{ Avrami Parameters ${ }^{a}$} \\
\hline & $t_{0}^{b}$ & $n$ & $\log k$ & $t_{1 / 2}$ & & $t_{o}^{b}$ & $n$ & $\log k$ & $t_{1 / 2}$ \\
\hline $170^{\circ} \mathrm{C}$ & 0.2 & 1.6 & -0.4 & 1.6 & $150^{\circ} \mathrm{C}$ & 0.1 & 1.5 & -0.4 & 1.6 \\
\hline $180^{\circ} \mathrm{C}$ & 0.3 & 2.5 & -0.9 & 2.2 & $160^{\circ} \mathrm{C}$ & 0.2 & 1.7 & -0.5 & 1.7 \\
\hline $190^{\circ} \mathrm{C}$ & 0.5 & 2.5 & -1.6 & 3.7 & $170^{\circ} \mathrm{C}$ & 0.4 & 2.3 & -0.9 & 2.5 \\
\hline $200^{\circ} \mathrm{C}$ & 3.4 & 2.9 & -2.5 & 10.1 & $180^{\circ} \mathrm{C}$ & 1.1 & 2.6 & -1.6 & 4.6 \\
\hline
\end{tabular}

${ }^{a}$ Avrami exponent $n$, constant of crystallization, and crystallization half-time $t_{1 / 2}(\min )$.

${ }^{b}$ Onset crystallization time (min). 